\title{
Short-Term Increases in Transient Receptor Potential Vanilloid-1 Mediate Stress-Induced Enhancement of Neuronal Excitation
}

\author{
Carl Weitlauf, Nicholas J. Ward, Wendi S. Lambert, Tatiana N. Sidorova, Karen W. Ho, Rebecca M. Sappington, \\ and David J. Calkins \\ Vanderbilt Eye Institute, Vanderbilt University Medical Center, Nashville, Tennessee 37232-0654
}

\begin{abstract}
Progression of neurodegeneration in disease and injury is influenced by the response of individual neurons to stressful stimuli and whether this response includes mechanisms to counter declining function. Transient receptor potential (TRP) cation channels transduce a variety of disease-relevant stimuli and can mediate diverse stress-dependent changes in physiology, both presynaptic and postsynaptic. Recently, we demonstrated that knock-out or pharmacological inhibition of the TRP vanilloid-1 (TRPV1) capsaicin-sensitive subunit accelerates degeneration of retinal ganglion cell neurons and their axons with elevated ocular pressure, the critical stressor in the most common optic neuropathy, glaucoma. Here we probed the mechanism of the influence of TRPV1 on ganglion cell survival in mouse models of glaucoma. We found that induced elevations of ocular pressure increased TRPV1 in ganglion cells and its colocalization at excitatory synapses to their dendrites, whereas chronic elevation progressively increased ganglion cell Trpv1 mRNA. Enhanced TRPV1 expression in ganglion cells was transient and supported a reversal of the effect of TRPV1 on ganglion cells from hyperpolarizing to depolarizing, which was also transient. Short-term enhancement of TRPV1-mediated activity led to a delayed increase in axonal spontaneous excitation that was absent in ganglion cells from $\operatorname{Trpv1^{-/-}}$ retina. In isolated ganglion cells, pharmacologically activated TRPV1 mobilized to discrete nodes along ganglion cell dendrites that corresponded to sites of elevated $\mathrm{Ca}^{2+}$. These results suggest that TRPV1 may promote retinal ganglion cell survival through transient enhancement of local excitation and axonal activity in response to ocular stress.
\end{abstract}

\section{Introduction}

Neurodegeneration in disease and injury involves not only pathogenic processes but also prosurvival mechanisms to counter degradation of function in response to stress. Members of the transient receptor potential (TRP) family of cation-selective ion channels respond to a variety of stress-related stimuli (Lin and Corey, 2005; Ho et al., 2012; Vennekens et al., 2012). The capsaicin (CAP)-sensitive TRP vanilloid-1 (TRPV1) channel contributes to tactile sensitivity, diabetic sensory neuropathy, pressure-induced pain, injury monitoring, and visceral distension (Mutai and Heller, 2003; Hwang et al., 2004; Rong et al.,

\section{Received Aug. 15, 2014; revised Sept. 17, 2014; accepted 0ct. 6, 2014}

Author contributions: C.W., N.J.W., R.M.S., and D.J.C. designed research;C.W., N.J.W., W.S.L., T.N.S., K.W.H., and R.M.S. performed research; C.W., N.J.W., R.M.S., and D.J.C. analyzed data; C.W., N.J.W., and D.J.C. wrote the paper.

This work was supported by National Institutes of Health (NIH) Grants EY017427 (D.J.C.), 5T32EY007135-18 (N.J.W.), and T32GM007628-32 (K.W.H.), Senior Scientific Investigator and Departmental Unrestricted Awards from Research to Prevent Blindness (D.J.C.), the BrightFocus Foundation (D.J.C.), and the Glaucoma Research Foundation (D.J.C.). Imaging was supported through the Vanderbilt University Medical Center Cell Imaging Shared Resource core facility (Clinical and Translational Science Award Grant UL1 RR024975 from National Center for Research Resources/NIH) and the Vanderbilt Vision Research Center (NIH Grant P30EY008126). We acknowledge Brian J. Carlson and Kelsey Karas for their assistance with the project.

The authors declare no competing financial interests.

Correspondence should be addressed to David J. Calkins, Department of Ophthalmology and Visual Sciences, Vanderbilt Eye Institute, Vanderbilt University Medical Center, 11425 Medical Research Building IV, Nashville, TN 37232-0654. E-mail: david.j.calkins@vanderbilt.edu.

DOI:10.1523/JNEUROSCI.3424-14.2014

Copyright $\odot 2014$ the authors $\quad 0270-6474 / 14 / 3415369-13 \$ 15.00 / 0$
2004; Scotland et al., 2004; Jones et al., 2005; Ma et al., 2005; Liedtke, 2006; Plant et al., 2006; Daly et al., 2007; Pingle et al., 2007). Activation of TRPV1 induces a robust $\mathrm{Ca}^{2+}$ conductance that supports intracellular signaling cascades for both normal physiology and stress-related processes (Agopyan et al., 2004; Aarts and Tymianski, 2005; Reilly et al., 2005; Kim et al., 2006; Miller, 2006). Stimuli that activate TRPV1 can also increase the expression, sensitization, and translocation of the receptor to the plasma membrane (Kanai et al., 2005; Zhang et al., 2005; Facer et al., 2007; Schumacher and Eilers, 2010). In injury, TRPV1 is shuttled to damaged axons, in which it enhances spontaneous excitation (Biggs et al., 2008), and TRPV1-gated $\mathrm{Ca}^{2+}$ can potentiate glutamatergic signaling and contribute to cytoskeletal remodeling (Medvedeva et al., 2008; Jiang et al., 2009; Goswami et al., 2010; Peters et al., 2010). TRPV1 is also implicated in forms of synaptic remodeling, including long-term potentiation and depression (Li et al., 2008; Chávez et al., 2010).

Retinal ganglion cell neurons express TRPV1 and other TRP subunits, which can increase intracellular $\mathrm{Ca}^{2+}$ when activated and influence survival of ganglion cells challenged by stressors such as ischemia and elevated ocular pressure (Nucci et al., 2007; Maione et al., 2009; Sappington et al., 2009; Wang et al., 2010; Ryskamp et al., 2011; Leonelli et al., 2013).The latter is especially relevant for neurodegenerative disease, because pressure is a critical risk factor in glaucoma, the most common optic neuropathy and leading cause of irreversible blindness worldwide (Quigley 
and Broman, 2006). Recently, we demonstrated that knock-out of TRPV1 in mice ( $\operatorname{Trpv1}{ }^{-/-}$) or prolonged pharmacological antagonism of TRPV1 in rats using an inducible model of glaucoma accelerated ganglion cell axonal and somatic degeneration with exposure to elevated intraocular pressure (IOP) for 5 weeks (Ward et al., 2014). Importantly, ganglion cells from Trpv1 ${ }^{-/-}$ retina lacked a compensatory increase in spontaneous action potentials with elevated pressure and required greater depolarization to reach firing threshold. Here we demonstrate that exposure to elevated IOP in the same inducible model increased expression and localization of TRPV1 at excitatory synapses to ganglion cell dendrites. This effect was early and transient, as was the capacity of TRPV1 to promote physiological excitation by reversal of its net influence from hyperpolarizing to depolarizing. Finally, activation of TRPV1 in ganglion cells induced translocation to dendritic nodes that gated an increase in intracellular $\mathrm{Ca}^{2+}$. Together, these results suggest that TRPV1 promotes neuronal survival in response to disease-relevant stressors by transient enhancement of local excitation at postsynaptic sites.

\section{Materials and Methods}

Animals. Adult (1-4 months old) C57BL/6 (C57) mice were obtained from Charles River Laboratories, whereas adult DBA/2J (3-12 months old) and the age-matched transgenic control strain D2-Gpnmb+ (D2; Howell et al., 2007a,b) were obtained from The Jackson Laboratory, as were adult (1 month old) male Trpv1 ${ }^{-1-}\left(\mathrm{B} 6.129 \mathrm{X} 1-\operatorname{Trp} v 1^{\text {tm1Jul }} / \mathrm{J}\right)$ mice; Caterina et al., 2000; Ciura and Bourque, 2006; Treesukosol et al., 2007). Following Ward et al. (2014), these were genotyped before experimentation to confirm the transgene, following protocols provided by The Jackson Laboratory. For primary cultures of purified retinal ganglion cells, eyes from postnatal days 4-7 Sprague Dawley rats were enucleated, and their retinas were removed as described previously (Sappington et al., 2006, 2009). The Vanderbilt University Medical Center Institutional Animal Care and Use Committee approved all experimental procedures. Mice were maintained in a $12 \mathrm{~h}$ light/dark cycle with standard rodent chow available ad libitum.

We measured IOP bilaterally in anesthetized (2.5\% isoflurane) mice using a TonoPen XL rebound tonometer (Medtronic Solan) as described previously (Inman et al., 2006; Sappington et al., 2010). For C57 and male $\operatorname{Trp} v 1^{-1-}$ mice, we monitored IOP for 2-3 $\mathrm{d}$ to give an average baseline IOP value (day 0 ). We elevated IOP by injecting only once $1.5 \mu \mathrm{l}$ of 15 $\mu \mathrm{m}$ polystyrene microbeads (Invitrogen) into the anterior chamber of one eye, with the contralateral eye serving as internal control by receiving an equivalent volume of saline, as described previously (Crish et al., 2010; Sappington et al., 2010). We measured IOP in a subset of DBA/2 mice up to 10 months of age using the Tono-Pen XL (Medtronic Solan) as described previously (Inman et al., 2006).

Immunolabeling and confocal imaging. For immunohistochemistry studies of TRPV1 localization, cohorts of mice ( $n=3-5$ animals each) were killed at $4 \mathrm{~d}$ and $1,3,5$, and 7 weeks after microbead injection. Immunolabeling of retinal sections was performed as described previously and at identical conditions between sets using a highly specific rabbit anti-TRPV1 (1:100; Neuromics) and mouse anti-postsynaptic density protein 95 (PSD-95; 1:200; Millipore; Sappington et al., 2009; Dapper et al., 2013). Sections were counterstained for cell nuclei using 4',6-diamidino-2-phenylindole dihydrochloride (DAPI; 1:100 in $\left.\mathrm{ddH}_{2} \mathrm{O}\right)$.

Confocal imaging was done through the Vanderbilt University Medical Center Cell Imaging Shared Resource using identical microscope settings to acquire images for signal quantification. This was done by a naive observer using custom routines in NIH ImageJ. Fluorescent intensity of immunolabeled proteins was determined within outlined retinal layers and averaged over the selected area of pixels. Using FluoView software (Olympus), colocalization of TRPV1 and PSD-95 in the retina was examined by using stacked micrographs through multiple optical planes of retinal tissue. For each section, we drew multiple random horizontal lines across the region of interest and identified the number of pixels above an intensity threshold of 50 for either the TRPV1 or PSD-95 channel. Of that subset, the fraction of them above threshold for both channels was calculated, and colocalization was expressed as the ratio of pixels above threshold for TRPV1 and PSD-95 to the number of pixels above threshold for either.

Quantitative RT-PCR. We extracted RNA from retina of naive and saline- or microbead-injected C57 eyes and of DBA2J and D2 eyes as described previously (Hanna and Calkins, 2006; Crish et al., 2013). Quantitative PCR (qPCR) was performed using an ABI Prism 7300 RealTime PCR System and a FAM dye-labeled gene-specific probe for Trpv1 (Applied Biosystems). Cycling conditions and cycle threshold values were automatically determined by the supplied ABI software (SDS version 1.2). Relative product quantities for the $\operatorname{Trp} v 1$ transcript were performed in triplicate and determined using the $2 \Delta \Delta \mathrm{Ct}$ analysis method (Livak and Schmittgen, 2001), with normalization to 18 S rRNA as an endogenous control.

Fluorescent in situ hybridization with immunolabeling. Following our published protocol (Crish et al., 2013), to generate Trpv1 mRNA probes, total RNA from C57 mouse brain was extracted using RNeasy Mini kit (Qiagen), and first-strand cDNA synthesis was performed using Superscript III reverse transcriptase (Invitrogen). An antisense probe recognizing Trpv1 mRNA was made against a nucleotide sequence present in mouse Trpv1 (nucleotides 226-500 of GenBank accession number NM_001001445). A transcript generated by PCR using primers to Trpv1 (forward, 5'-ATC ACC GTC AGC TCT GTT GTC ACT-3' and reverse, 5'-TGC AGA TTG AGC ATG GCT TTG AGC-3') was inserted into pGEM-T Easy Vector (Promega), and orientation was verified by sequencing. Isolated plasmids were linearized and purified, and labeled Trpv1 RNA probes were generated using SP6 and T7 RNA polymerases and Digoxigenin RNA Labeling Mix (Roche Applied Science). Probe concentration and quality $\left(A_{260} / A_{280}\right.$ ratio $)$ were determined using a NanoDrop spectrophotometer. Probes were stored at $-80^{\circ} \mathrm{C}$.

Fluorescent in situ hybridization was performed using flat-mounted retinas as described previously (Crish et al., 2013). Immmunodetection of labeled Trpv1 mRNA was performed using anti-DIG-Fab-POD conjugate (Roche) diluted 1:100 in blocking buffer [1\% blocking reagent (Roche) in $0.1 \mathrm{~m}$ Tris, $\mathrm{pH} 7.5$, and $0.15 \mathrm{M} \mathrm{NaCl}$ ], followed by detection using the TSA plus Fluorescein system (PerkinElmer Life and Analytical Sciences). Immunolabeling for retinal ganglion cells in the same tissue was performed with antibodies to phosphorylated heavy-chain neurofilament (1:1000, SMI31; Sternberger Monoclonals). For quantification, five confocal images were captured per retina, and labeled Trpv1 mRNA was quantified in 5-10 randomly selected retinal ganglion cells per image using ImagePro Analyzer 6.3 (Media Cybernetics).

Whole-cell patch-clamp recordings. Additional C57 mice were killed up to either 2 weeks ( $4-15 \mathrm{~d})$ or 4 weeks (18-28 d) after microbead injections as described above. These mice yielded 71 and 28 saline-injected and 85 and 26 microbead-injected eyes for the 2 and 4 week groups, respectively. Similarly, Trpv1 ${ }^{-1-}$ mice were killed $12-28 \mathrm{~d}$ after injections, yielding 14 each of saline and microbead retinas. Following our previous work (Ward et al., 2014), retinas were removed, hemisected, and transferred to oxygenated Ames solution in a temperature-controlled perfusion chamber with the ganglion cell layer up in the dark at room temperature. Ganglion cells (typically from the midperipheral retina) were whole-cell current clamped with borosilicate glass electrodes (5-10 $\mathrm{M} \Omega$ ) containing $130 \mathrm{~mm}$ K-gluconate, $10 \mathrm{~mm} \mathrm{KCl,} 10 \mathrm{~mm}$ HEPES, $2 \mathrm{~mm}$ $\mathrm{MgCl}_{2}, 1$ mм EGTA, 2 mм Na2ATP, $0.3 \mathrm{~mm} \mathrm{NaGTP}$, and 1\% Lucifer yellow dye (Life Technologies) to visualize dendritic morphology. For cells that did not show a spontaneous action potential firing rate $>0.5$ $\mathrm{Hz}$, a $1 \mathrm{~s}$ depolarizing step current ranging from 25 to $200 \mathrm{pA}$ was delivered at $0.1 \mathrm{~Hz}$ until the firing rate exceeded $3 \mathrm{~Hz}$. Ganglion cells for which action potentials did not maintain a constant firing rate for a minimum of $4 \mathrm{~min}$ were excluded, as were cells for which membrane resistance changed by $>20 \%$. Drugs were bath perfused and included the TRPV1specific agonists CAP $(2 \mu \mathrm{M})$ and N-oleoyldopamine (N-OLDA; $10 \mu \mathrm{M}$; Medvedeva et al., 2008) and the TRPV1-specific antagonist iodoresiniferatoxin (IRTX; $100 \mathrm{nM}$ ). CAP in the $1-10 \mu \mathrm{M}$ concentration range enhances excitatory transmission in a variety of brain structures (Marinelli et al., 2003; Li et al., 2004; Xing and Li, 2007). A $10 \mu \mathrm{M}$ dose of 

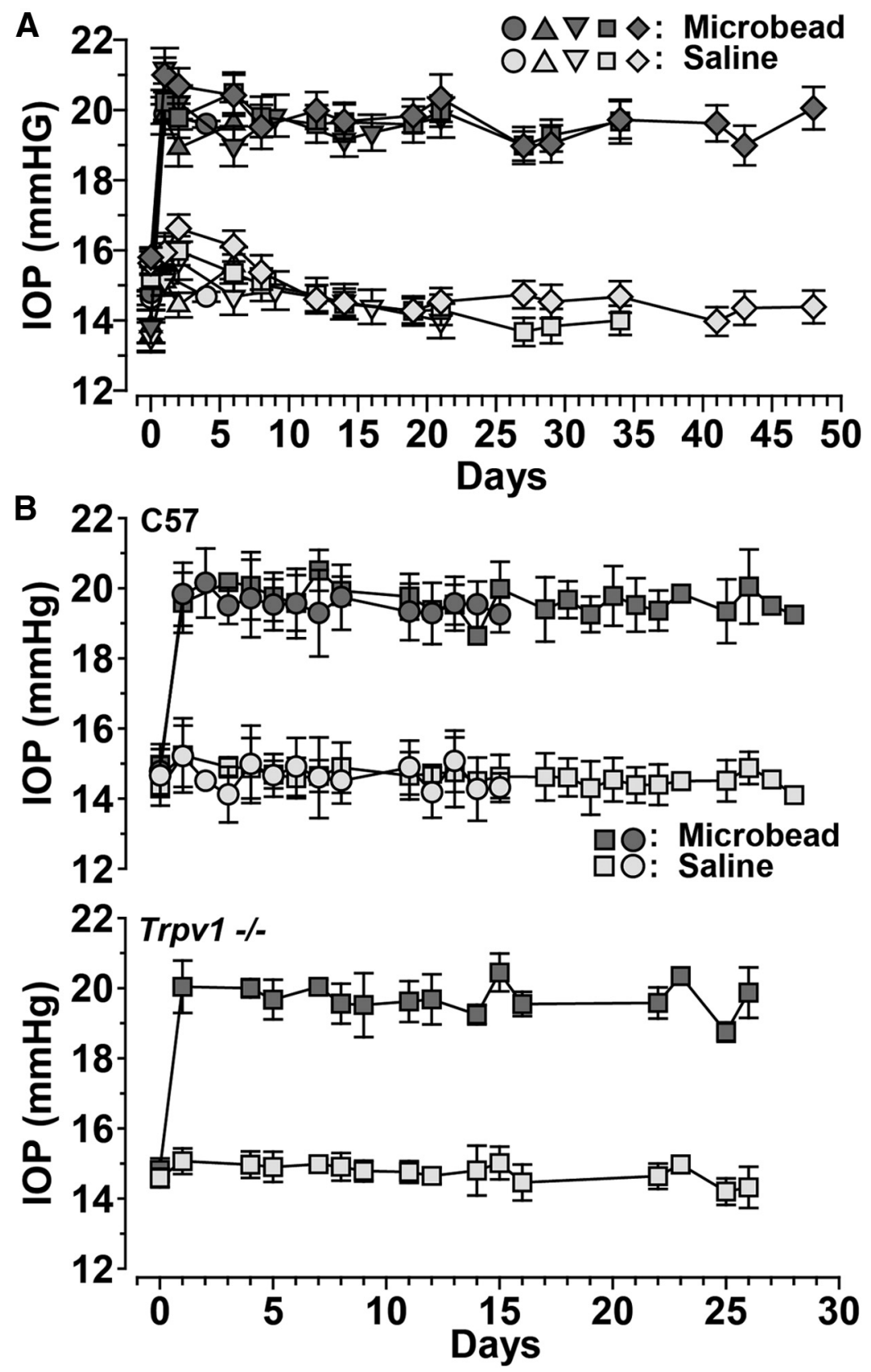

Figure 1. Microbead-induced elevations in mouse IOP. A, Daily average of IOP for $\mathrm{C} 57$ eyes used in labeling studies before (day 0 ) and after (days $\geq 1$ ) a single unilateral injection of polystyrene microbeads ( $1.5 \mu \mathrm{l}$ ) or an equivalent volume of saline. Cohorts followed from $4 \mathrm{~d}$ (circles) to 7 weeks (diamonds). Microbead eyes exhibited an increase of 31-34\% $(19.68-19.84 \pm 0.15-0.39)$ that was significant compared with saline eyes $(14.69-15.04 \pm 0.12-0.25)$ for all cohorts $(p<0.001)$. Between cohorts, IOP was similar for saline $(p=0.38)$ and microbead $(p=0.65)$ eyes. $\boldsymbol{B}$, Average daily IOP in eyes used for physiological studies was similarly elevated (32-34\%) by microbead injection for up to 2 (circles) or 4 (squares) weeks for (57 eyes (19.56 \pm 0.26 and $19.65 \pm 0.39$, respectively) and for just under 4 weeks in Trpv ${ }^{-1-}$ eyes $(19.73 \pm 0.42)$. Errors indicated are SD. IOP was similar for both saline $(p \geq 0.15)$ and microbead ( $p \geq 0.15)$ eyes for all cohorts.

N-OLDA has similar effects (Spicarova and Palecek, 2009), whereas IRTX is an effective inhibitor at submicromolar concentrations (Wahl et al., 2001). After recording, retinas were fixed in $4 \%$ paraformaldehyde overnight and mounted for confocal microscopy as described above.

Purified retinal ganglion cell primary cultures and $\mathrm{Ca}^{2+}$ imaging. Primary cultures of purified ganglion cells were prepared as described previously by immunomagnetic separation using mouse anti-rat Thy1.1/ CD90 IgG (5 $\mu \mathrm{g} / \mathrm{ml}$; BD Pharmingen) and metallic microbeads conjugated with anti-mouse IgG (Sappington et al., 2006, 2009). To as- sess TRPV1-mediated changes in accumulated intracellular $\mathrm{Ca}^{2+}$, we used the BAPTA-based $\mathrm{Ca}^{2+}$ indicator dye Fluo-4 AM (Invitrogen; Kreitzer et al., 2000; Sappington et al., 2009), which exhibits a 40 -fold increase in fluorescence intensity with $\mathrm{Ca}^{2+}$ binding (Gee et al., 2000). Primary cultures were loaded with $5 \mu \mathrm{M}$ Fluo-4 for $30 \mathrm{~min}$, assessed for comparable loading, and then treated for 30 min with either CAP $(100 \mathrm{~nm}$ or $1 \mu \mathrm{M})$ or its vehicle $(\mathrm{ETOH})$ or CAP $(1 \mu \mathrm{M})$ and $950 \mu \mathrm{M}$ EGTA (Gibco), which reduced the concentration of available $\mathrm{Ca}^{2+}$ to $100 \mu \mathrm{M}$, as determined by Maxchelator (Stanford University, Stanford, CA). Live cultures were coverslipped with physiological saline and imaged using confocal microscopy. For each sample, 15-20 independent fields were acquired, and Fluo-4 intensity was quantified using Image Pro Plus (version 5.1.2; Media Cybernetics). After imaging of accumulated $\mathrm{Ca}^{2+}$, ganglion cell cultures were fixed briefly, immunolabeled for TRPV1 and SMI31, and imaged using confocal microscopy as described above.

Statistical analyses. Unless otherwise indicated, all data are expressed as mean $\pm \mathrm{SE}$; the number of samples used in each experiment is given in the appropriate description in Materials and Methods or figure legend. Statistical comparisons between two independent measurements were made using two-sided $t$ tests, after confirmation of normality for each using the Shapiro-Wilk normality test; samples for which normality failed were compared using the Mann-Whitney rank-sum test (SigmaPlot 11.1; Systat Software). Comparisons of a sample mean to a hypothesized or predicted value were made using a one-sided $t$ test. Comparisons between multiple groups were made using Kruskal-Wallis one-way ANOVA on ranks (SigmaPlot 11.1; Systat Software). Actual pvalues of significance are indicated when appropriate in Results or figure legends. All comparisons for which significance is reported achieved or exceeded a post hoc calculation of power of 0.80 .

\section{Results}

Elevated ocular pressure increases TRPV1 transiently at retinal synapses We elevated IOP for various durations in cohorts of C57 and Trpv1 $1^{-/-}$mice by microbead occlusion of aqueous fluid in the anterior eye (Sappington et al., 2010; Chen et al., 2011). A single unilateral microbead injection elevated IOP by $31-34 \%$ for up to 7 weeks in C57 eyes intended for expression studies (Fig. 1A) and by $32-34 \%$ for up to 4 weeks in C57 or Trpv1 ${ }^{-/-}$eyes intended for physiological studies (Fig. 1B). All IOP measurements were similar to those we described recently in C57 and $\operatorname{Trp} v 1^{-/-}$eyes for a slightly lesser volume injection $(1.0 \mu \mathrm{l}$; Ward et al., 2014).

Immunolabeling for TRPV1 in retina from saline-injected control eyes was generally modest in all cohorts (Fig. $2 \mathrm{~A}$, top row), with clear localization near ganglion cell neurons and in the nerve fiber layer in which their axons extend. This is consistent 
A
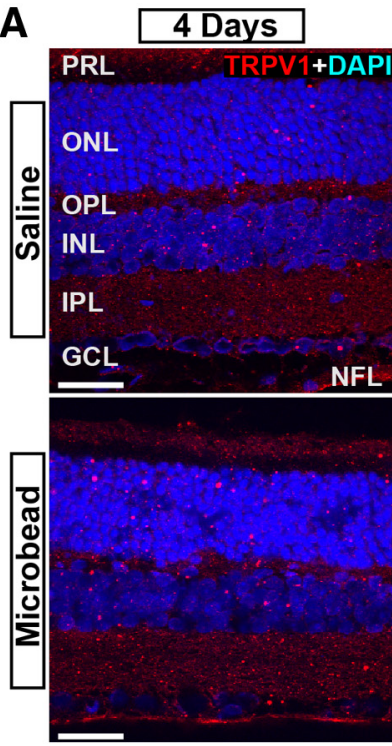

B

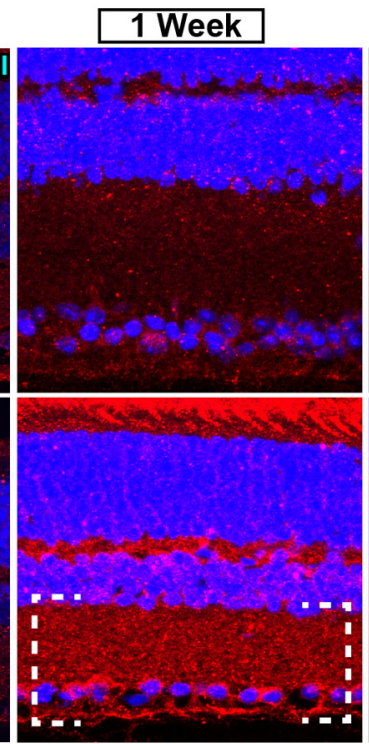

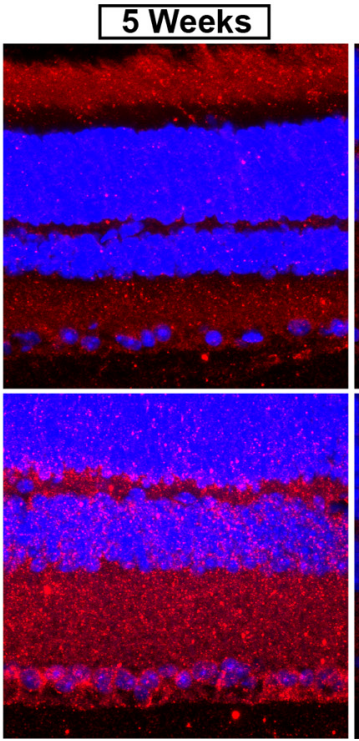

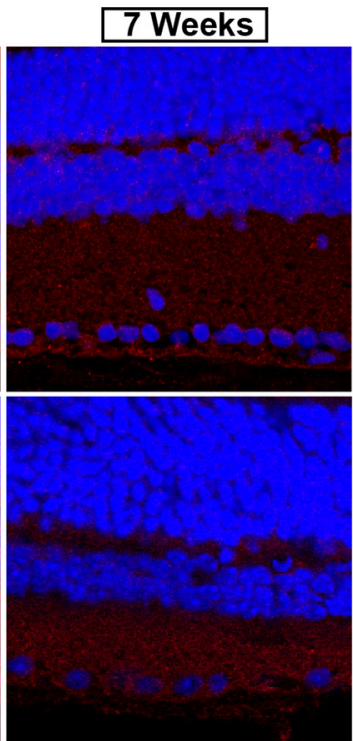

C

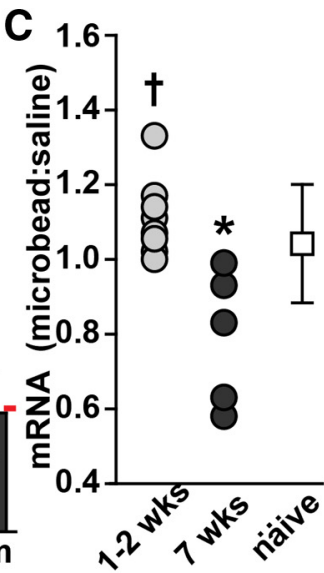

Figure 2. TRPV1 increases early with elevated IOP. A, Vertical sections through C57 retina immunolabeled against TRPV1 and counterstained with DAPI after microbead or saline injection (I0Ps in Fig. 1A). TRPV1 localization increases after 1 week of microbead-induced IOP elevation, especially for the ganglion cell layer (GCL) and inner plexiform layer (IPL; bracketed). PRL, Photoreceptor layer; ONL, outer nuclear layer; OPL, outer plexiform layer; INL, inner nuclear layer; NFL, nerve fiber layer. Scale bar, $20 \mu \mathrm{m}$. B, Quantification of TRPV1 for specific retinal layers indicated as ratio of microbead/saline eye. Increased ratio in the ganglion cell and inner plexiform layers at 1 week is significant compared with the ratio at $4 \mathrm{~d}\left({ }^{*} p \leq 0.026\right)$ and with a hypothetical ratio of one (dashed line; $\left.{ }^{\dagger} p \leq 0.046\right)$. C, qPCR measurements of TRPV1 mRNA expressed as ratio of microbead/saline retina after normalization to $185 \mathrm{rRNA}$ for pairs of eyes $1-2$ and $6-7$ weeks after injection. Ratio of TRPV1 mRNA at $1-2$ weeks $(1.12 \pm 0.04 ; n=8)$ exceeds the predicted ratio of one ( $\left.{ }^{\dagger} p=0.022\right)$, whereas the ratio at $6-7$ weeks $(0.79 \pm 0.08 ; n=5)$ is significantly lower than $1-2$ weeks $\left({ }^{*} p=0.002\right)$. IOP for saline and microbead eyes was similar to that in Figure 1. Average TRPV1 mRNA level for naive retina shown for comparison $(1.04 \pm 0.16 ; n=12)$.

with previous work in naive retina (Leonelli et al., 2009, 2010; Sappington et al., 2009). Microbead-induced elevated IOP increased TRPV 1 transiently by 1 week, with a return to saline-eye levels by later times (Fig. 2A, bottom row). Although TRPV1 label increased throughout the retina, when quantified, the only significant changes were in the ganglion cell layer and inner plexiform layer, in which ganglion cell dendritic arbors ramify and receive synaptic contacts (Fig. $2 B$ ). The increase in TRPV1 was transient, diminishing to levels in saline retina by 5 weeks. Quantitative RT-PCR measurements showed that expression of Trpv1 mRNA in the retina increased transiently after 1-2 weeks of elevated IOP, diminishing significantly by 7 weeks (Fig. 2C).

In naive mouse retina, TRPV1 localizes strongly to both ganglion cell bodies identified by a cell-specific marker and in the inner plexiform layer to neuronal processes expressing PSD-95 (Fig. $3 A, B$ ), a marker for excitatory synapses in the retina (Cho and So, 1992; Koulen et al., 1998; Jakobs et al., 2008). Microbeadinduced elevations in IOP also increased PSD-95 localization transiently in the inner plexiform layer, reaching a peak by 1 week that subsided by 5 weeks (Fig. 3C). Quantification on a pixel-by- pixel basis indicated a significant threefold increase in pixels colabeled with TRPV1 and PSD-95 expressed as the ratio of microbead/saline retina at 1 week (3.8 ratio) compared with $4 \mathrm{~d}$ ( 1.3 ratio; $p=0.023$ ).

TRPV1 localization to ganglion cells increases with elevated IOP and age in the DBA2J mouse model of hereditary glaucoma (Sappington et al., 2009). This inbred strain presents agedependent elevations in IOP induced by iris atrophy and pigment dispersion caused by mutations in the tyrpl and gpnmb genes, respectively (Howell et al., 2007a,b). Here, quantitative RT-PCR of retinal mRNA showed that Trpv1 expression in young (3-5 months old) DBA2J retina is $\sim 50 \%$ of that from retina from the age-matched D2 control strain (Fig. 4A). Elevated IOP increased Trpv1 approximately threefold for both young and aged (8-10 months old) DBA2J retina (Fig. 4A). Even for eyes with a narrow range of low IOPs ( $<15 \mathrm{mmHg}$ ), Trpv1 expression scaled with increasing pressure (Fig. $4 A$, inset). We then combined fluorescent in situ hybridization for Trpv1 antisense mRNA with immunolabeling for phosphorylated neurofilaments, which selectively marks ganglion cells (Howell et al., 2007b; Soto et al., 2008; Crish 

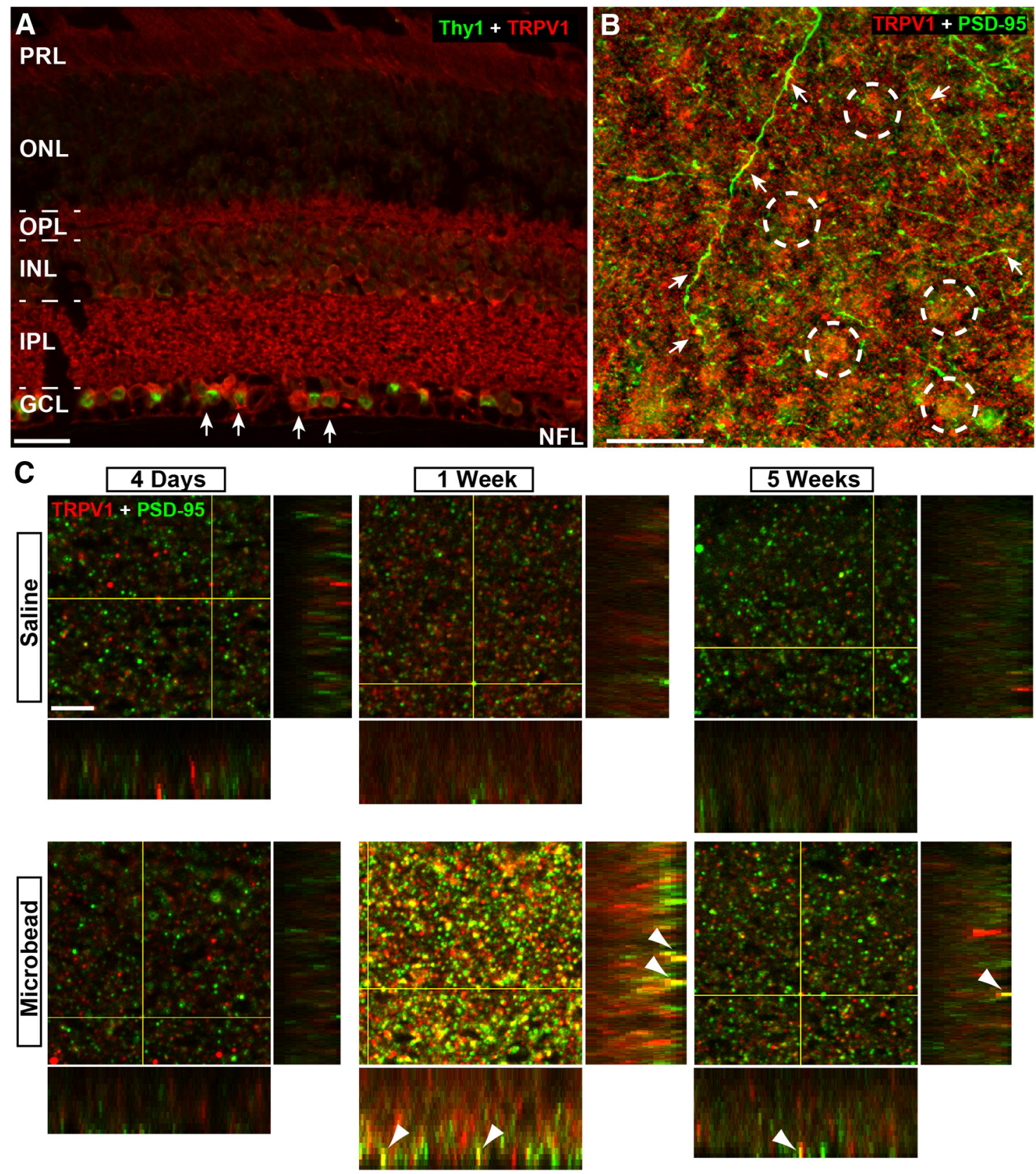

Figure 3. Colocalization of TRPV1 and PSD-95 increases transiently. A, Thy1-labeled ganglion cells in naive C 57 retina (arrows) expressing TRPV1. B, Single confocal plane through the border of the inner plexiform and ganglion cell layers of C57 retina shows TRPV1 localizing at discrete positions along neuronal processes (arrows) and around cell bodies (circles) outlined by PSD-95 localization. C, High-magnification single confocal planes through inner plexiform layer after microbead or saline injection (IOPs in Fig. 1). Increased colocalization of PSD-95 and TRPV1 after 1 week of elevated IOP indicated (arrowheads) in orthogonal slices at specific locations in image plane (lines). Scale bars: $A, B, 20 \mu \mathrm{m} ; C, 5 \mu \mathrm{m}$. GCL, Ganglion cell layer; IPL, inner plexiform layer; bracketed; PRL, photoreceptor layer; ONL, outer nuclear layer; OPL, outer plexiform layer; INL, inner nuclear layer; NFL, nerve fiber layer.

et al., 2010). Compared with antisense label against ganglion cellspecific Thy 1 mRNA as a positive control (Fig. $4 B$ ), Trpv1 mRNA in C57 retina distributed lightly in $\sim 70 \%$ of ganglion cells (Fig. $4 C)$. We observed a similar pattern in 3-month-old DBA2J ganglion cells (Fig. 4D). By 8 months, DBA2J ganglion cells demonstrated a clear increase in Trpv1 expression (Fig. 4E, left) that dissipated by 12 months (Fig. 4E, right). When quantified, signal forTrpv1 antisense increased significantly by $6-8$ months compared with 3 months; by 12 months, Trpv1 expression returned to 3 month levels (Fig. $4 F$ ). In no case did the control sense sequence elicit detectable label (Fig. 4B-E). Interestingly, DBA2J ganglion cells with accumulation of phosphorylated neurofilaments in their dendritic arbors, which signifies pathogenic progression (Howell et al., 2007b; Soto et al., 2008), had 50\% less Trpv1 antisense signal on a cell-by-cell basis (Fig. 4G,H). These results indicate that, like microbead-induced elevated IOP, chronic stress also transiently increases Trpv1 mRNA with changes detectable in single ganglion cells.

\section{Elevated pressure transiently enhances TRPV1-mediated excitation}

Next we probed whether increased TRPV1 at excitatory synapses with elevated IOP in the C57 retina could influence ganglion cell physiology using patch-clamp voltage recording from microbead 

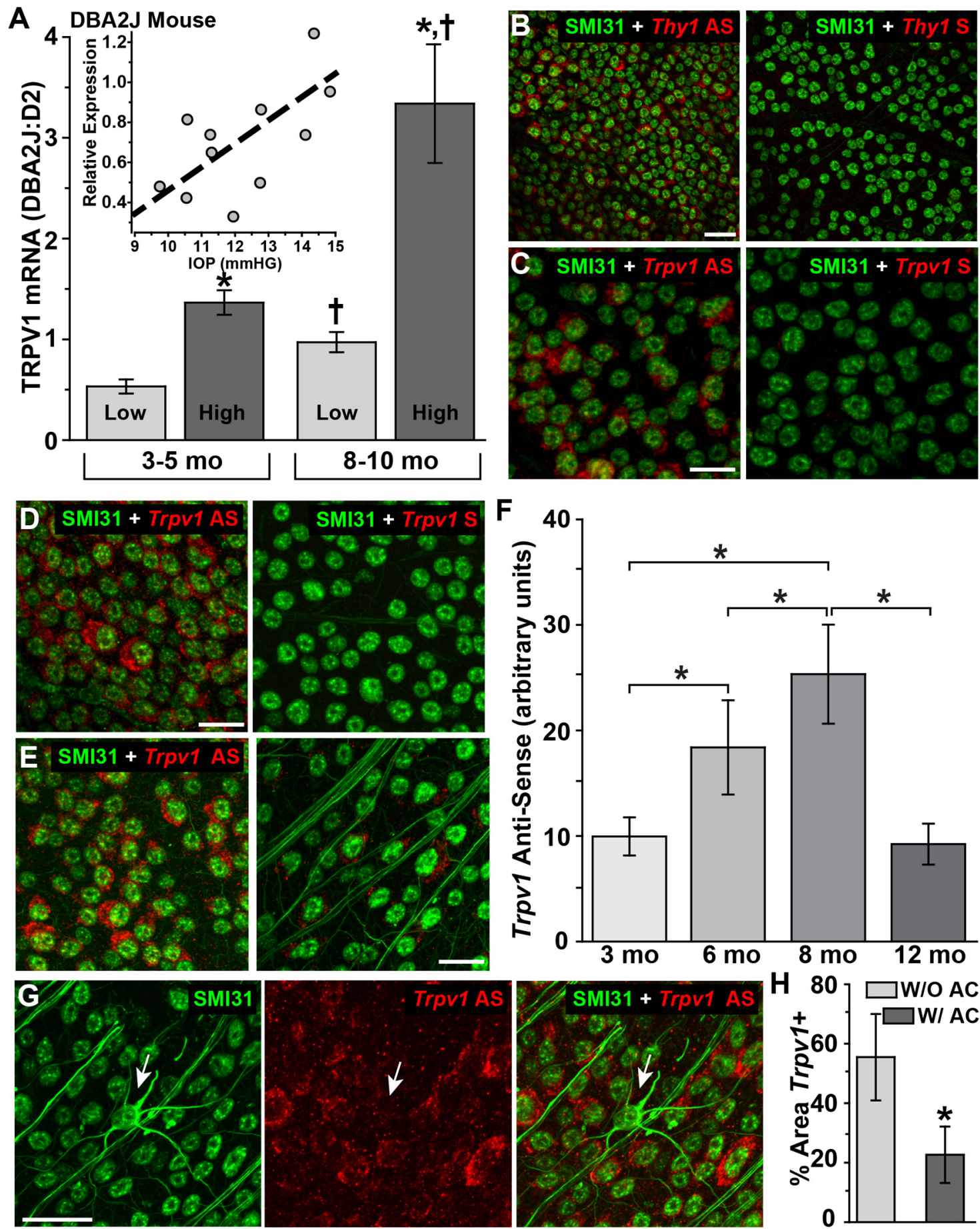

Figure 4. Increased TRPV1 mRNA in ganglion cells of the DBA2J mouse retina. $A$, Bar graphs, qPCR measurements of Trpv1 mRNA in DBA2J retina relative to levels in age-matched D2 control retina; both calculated relative to 185 rRNA. For the 3-5 month group, retinas from eyes with higher IOP (17.00 $\pm 0.52 \mathrm{mmHg})$ demonstrated threefold higher Trpv 1 than those from lower IOP eyes $\left(11.11 \pm 0.46 \mathrm{mmHg}\right.$ ), as did higher IOP retinas from the $8-10$ month group ( $17.62 \pm 0.86 \mathrm{mmHg}$ ) compared with low IOP counterparts ( $14.11 \pm 0.84 \mathrm{mmHg} ;{ }^{*} p \leq$ 0.017). The 8-10 month low- and high-IOP samples also had greater Trpv1 than their $3-5$ month counterparts $\left({ }^{\dagger} p \leq 0.05\right)$. Sample size: $n=6$ for each. Inset, Trpv1 mRNA in DBA2J relative to $\mathrm{D} 2$ retinas from eyes within the low IOP groups $\left(<15 \mathrm{mmHg}\right.$ only) with best-fitting regression line $\left(r^{2}=0.53 ; p=0.007\right)$. $\boldsymbol{B}$, Ganglion cells in flat-mounted naive $C 57$ retina colabeled with cell-specific Thy1 antisense (AS) probe and phosphorylated neurofilament antibodies (SMI31) as a positive control. Corresponding sense sequence (S) shown as negative control. C, SMI31 immunolabeled ganglion cells in C57 retina stained for Trpv1 antisense sequence. D, SMI31-labeled ganglion cells in DBA2J retina (3 months) colabeled with Trpv1 antisense probe (left) and control sense sequence (right). $\boldsymbol{E}$, An 8 month DBA2J retina (left) expresses higher levels of Trpv $1 \mathrm{mRNA}$ compared with 12 months (right). $\boldsymbol{F}$, Quantification of Trpv 1 antisense signal in individual DBA2J ganglion cells shows progressively increased expression from 3 to 8 months ( $\left.{ }^{*} p<0.001\right)$, with a subsequent decrease to 3 month levels by 12 months ( $p=0.65$ ). Sample size: $n=20-25$ cells per group. $G$, Ganglion cells in flat-mounted 12 month DB2J retina immunolabeled for SMI31 (left) and Trpv1 antisense probe (middle). Ganglion cells with accumulation of SMI31-labeled phosphorylated neurofilaments (arrows) show lower levels of Trpv1 expression (right). $\boldsymbol{H}$, Ganglion cells with SMI31 accumulation (W/ AC) show significantly lower fraction of cell body area containing Trpv1 signal compared with cells without accumulation (W/0 AC; $\left.{ }^{*} p<0.001\right)$. Scale bars: $\boldsymbol{B}-\boldsymbol{E}, 20 \mu \mathrm{m} ; \mathbf{G}, 30 \mu \mathrm{m}$. 

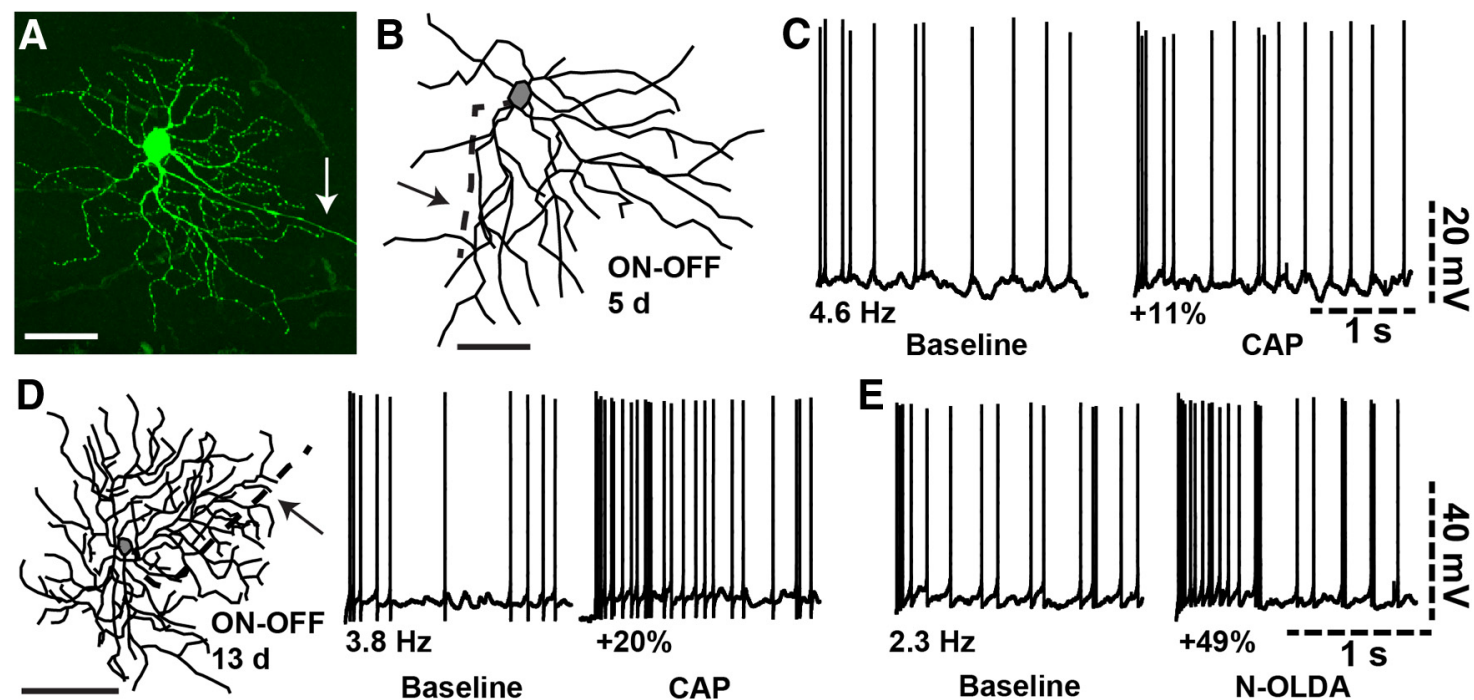

Figure 5. Elevated IOP increases TRPV1-mediated excitation. A, C57 ganglion cell filled with 1\% Lucifer yellow during whole-cell patch-clamp recording shows ramified dendrites and axon (arrow). B, Reconstruction of ON-OFF cell with axon (arrow) from saline eye $5 \mathrm{~d}$ after the fellow eye received microbead injection. $C$, Action potential recordings under current clamp from the cell shown in $\boldsymbol{B}$ before (left) and after (right) 3 min bath application of $2 \mu \mathrm{m}$ CAP, which increases firing $11 \%$ from the baseline rate of $4.6 \mathrm{~Hz}$. D, Reconstruction of $0 \mathrm{~N}-0 \mathrm{FF}$ ganglion cell with axon (arrow) from microbead retina $13 \mathrm{~d}$ after injection. Scale bar, $100 \mu \mathrm{m}$. Application of $2 \mu \mathrm{m}$ CAP increases firing rate by $20 \%$. F, Firing rate in $0 \mathrm{~N}-0 \mathrm{FF}$ cell from microbead retina $14 \mathrm{~d}$ after injection increases $49 \%$ after application of $10 \mu \mathrm{m} N-0 \mathrm{LDA}$. Scale bar applies to $D$ also. Scale bars: $A, B, 50 \mu \mathrm{m}$.

retinas (IOPs in Fig. 1B). For each ganglion cell targeted for recording in whole-mounted retina, we confirmed an intact axon and classified the cell as ON, OFF, or ON-OFF based on dendritic stratification after intracellular filling with Lucifer yellow to illuminate morphology (Fig. 5A). For an ON-OFF cell from a salineinjected eye (Fig. $5 B$ ), bath application of the TRPV1-specific agonist CAP $(2 \mu \mathrm{M})$ induced a modest $(11 \%)$ increase in rate of action potential generation from the spontaneous rate of $4.6 \mathrm{~Hz}$ (Fig. $5 C$ ). For an ON-OFF ganglion cell after $13 \mathrm{~d}$ of elevated IOP, CAP induced a $20 \%$ increase in firing rate (Fig. 5D). Application of a different TRPV1-specific agonist (N-OLDA, $10 \mu \mathrm{M}$ ) elicited a $49 \%$ increase in an ON-OFF ganglion cell after $14 \mathrm{~d}$ of elevated IOP (Fig. 5E). In these examples, TRPV1 contributes an excitatory effect on ganglion cell firing rate, with elevated IOP enhancing the effect.

Overall, however, TRPV1 had two very different effects on ganglion cell responses. We compared the responses of ganglion cells from microbead retina with those in corresponding saline retina for bath application of CAP or N-OLDA after brief (2 weeks) and more extensive (4 weeks) periods of elevated IOP as shown in Figure 1B. Interestingly, for the 2 week group, ganglion cells from saline retina on average responded to $3 \mathrm{~min}$ bath application of CAP or N-OLDA with a net reduction in firing rate relative to the spontaneous rate before application (Fig. 6A). This trend increased over the course of a recording. In contrast, ganglion cells from microbead retina in the 2 week cohort responded with a net increase in firing rate, consistent with the examples in Figure 5. However, by 4 weeks of elevated IOP, this excitatory enhancement had disappeared, with ganglion cells from microbead retina demonstrating the same net reduction in excitation as cells in saline retina (Fig. 6B). Saline eye responses were similar between the 2 and 4 week groups.

When averaged over the entire postdrug recording period ( 7 $\mathrm{min}$ ), the responses of individual cells from microbead retina in the 2 week cohort to the agonists were predominantly excitatory, with 19 of 31 cells (61\%) demonstrating an increase in firing rate that averaged $6 \%$ in amplitude (Fig. $6 C$ ). In contrast, $79 \%$ of ganglion cells from saline eyes in the same cohort demonstrated a reduction in firing rate that averaged 5\%. Both differed significantly from a prediction of no change from their predrug firing rate. By 4 weeks of elevated IOP, the response of ganglion cells from microbead and saline retinas were the same, and neither differed from their predrug firing rate (Fig. 6C). For each cohort, we did not detect any systematic differences between ON, OFF, or $\mathrm{ON}-\mathrm{OFF}$ ganglion cells, although the sample size for each type was limited. Finally, preapplication of the synthetic TRPV1specific antagonist IRTX nearly eradicated any change in firing rate attributable to CAP or N-OLDA for ganglion cells from either saline or microbead retinas (Fig. 6D). Thus, in the absence of stress induced by elevated IOP, TRPV1 activation by agonists primarily reduces ganglion cell excitation in intact retina. This effect was not an artifact attributable to recording, because neither membrane voltage nor membrane resistance changed significantly during the duration of our recordings and were the same for both saline and microbead ganglion cells ( $p=0.69$ and 0.35 , respectively; data not shown).

Recently, we found that 4 weeks of elevated IOP significantly increased spontaneous firing of action potentials for C57 ganglion cells; $\operatorname{Trpv1} 1^{-/-}$cells lacked this compensatory increase entirely for the same IOP elevation (Ward et al., 2014). Given the transient increase of TRPV1 in expression (Figs. 2, 3) and capacity to induce excitation (Fig. 6), we extended our previous result by comparing firing rates between the 2 versus 4 week cohorts for all ganglion cells that, in the absence of additional stimulation, spontaneously generated action potentials $(>0.5 \mathrm{~Hz})$. Ganglion cells in the 4 week C57 cohort demonstrated a $61 \%$ increase in spontaneous activity with elevated IOP compared with ganglion cells from corresponding saline retinas (Fig. 7A). This is consistent with our published finding (Ward et al., 2014). Even at 2 weeks, ganglion cells from microbead retinas had a $25 \%$ higher spontaneous firing rate compared with cells from saline retina (Fig. 7A), but this difference did not reach significance. In contrast, $\operatorname{Trpv1} 1^{-/-}$ganglion cells had no systematic difference in spontaneous rate for saline or microbead retinas for the entire range of times we examined $(12-28 \mathrm{~d} ; p=0.49)$. When pooled, $\operatorname{Trp} v 1^{-1-}$ ganglion cells from microbead retinas demonstrated a 

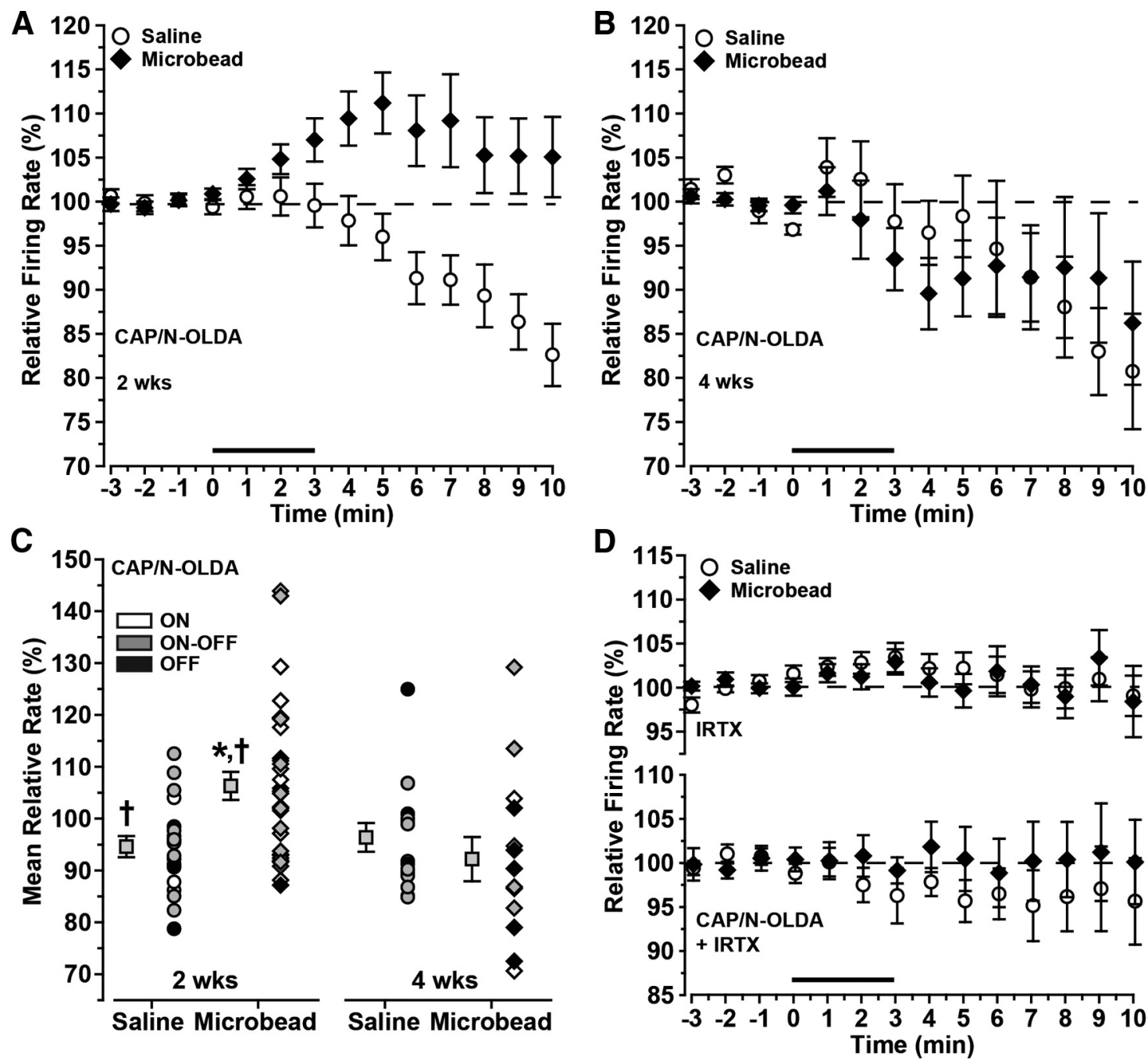

Figure 6. Increased TRPV1 excitation is transient. $A$, Average firing rate over time as a percentage of baseline rate ( -3 to 0 min) after application (solid line, $0-3$ min) of TRPV1 agonists CAP (2 $\mu \mathrm{M})$ or N-OLDA $(10 \mu \mathrm{M})$. Agonists cause a net reduction in rate for ganglion cells from saline eyes $(n=19)$ but a net increase in cells from microbead eyes $(n=31)$ after 2 weeks of IOP elevation $(p=0.001)$. B, After 4 weeks of IOP elevation, response to TRPV1 agonists is similar between microbead $(n=14)$ and saline $(n=15)$ cells $(p=0.78)$. Dashed line indicates no change from baseline rate (100\%). C, Mean firing rate in the period after application of TRPV1 agonists (3-10 $\mathrm{min})$ for individual ON, OFF, and ON-OFF ganglion cells from saline versus microbead retinas as a percentage of baseline. IOP elevation for 2 weeks increases the rate by $6 \%$ on average (106.3 $\pm 2.7 \%$ ), which differs significantly from the rate for saline cells $\left(94.6 \pm 2.0 \%\right.$; $\left.{ }^{*} p=0.007\right)$. Both means (squares) differ from a prediction of no change in rate (or $100 \% ;{ }^{\dagger} p \leq 0.026$ ). The response after 4 weeks is similar for ganglion cells from saline versus microbead retinas $(p=0.41)$, and neither group differs from a prediction of no change $(100 \% ; p \geq 0.10)$. Saline eye responses did not differ for the 2 and 4 week groups $(p=0.98)$. $\boldsymbol{D}$, Top trace, Average response to bath application of the TRPV1-specific antagonist IRTX over time is minimal and similar for saline $(n=20)$ and microbead ( $n=30)$ ganglion cells 2 weeks after injection ( $p=0.52)$. Bottom trace, Pretreatment (10 min) with IRTX inhibits agonist-induced differences in response between saline $(n=13)$ and microbead $(n=16)$ ganglion cells $(p=0.26)$.

spontaneous rate that was 37 and $42 \%$ less than rates for ganglion cells from the 2 and 4 week C57 microbead cohorts, respectively (Fig. 7A).

For ganglion cells in our sample with very low spontaneous firing rates $(<0.5 \mathrm{~Hz})$, we induced a rate of $3 \mathrm{~Hz}$ or higher by injecting steps of depolarizing currents (Fig. $7 B$ ). Ganglion cells of this class from C57 retinas required the same degree of depolarization (40-50 pA) for both 2 and 4 week cohorts and for saline and microbead eyes $(p=0.38)$. Although $\operatorname{Tr} p v 1^{-/-}$ganglion cells from saline retinas required the same threshold current as C57, cells from $\operatorname{Trpv1} 1^{-1-}$ microbead retina required $\sim 63 \%$ more depolarization to reach threshold. This threshold was the same for allTrpv1 $1^{-/-}$ganglion cells from microbead retinas, regardless of length of IOP elevation $(p=0.60)$. Together, our results suggest that ganglion cells from $\operatorname{Tr} p v 1^{-/-}$retina challenged by elevated IOP consistently demonstrate less spontaneous activity and require greater excitation to generate action potentials regardless of the duration of stress. Furthermore, the effects of increased TRPV1 expression appear to have a delayed influence on spontaneous ganglion cell activity, because only a longer exposure to elevated IOP ( 4 weeks) elicited a significant increase in firing rate (Fig. $7 A$ ).

Activation induces local translocation of TRPV1 and increased $\mathrm{Ca}^{2+}$

Activation of TRPV1 by ligands or physical stimuli can induce translocation of the channel to the plasma membrane with increased sensitization of the receptor (Zhang et al., 2005; Schumacher and Eilers, 2010). We found that, for isolated ganglion cells from naive retina, activation of TRPV1 with a low concentration of CAP (100 nM) caused little change in overall levels of Fluo-4conjugated $\mathrm{Ca}^{2+}$ but did concentrate signals within local nodes along dendritic processes (Fig. $8 A, B$ ). A 10-fold increase in CAP concentration $(1 \mu \mathrm{M})$ amplified this effect, along with overall 

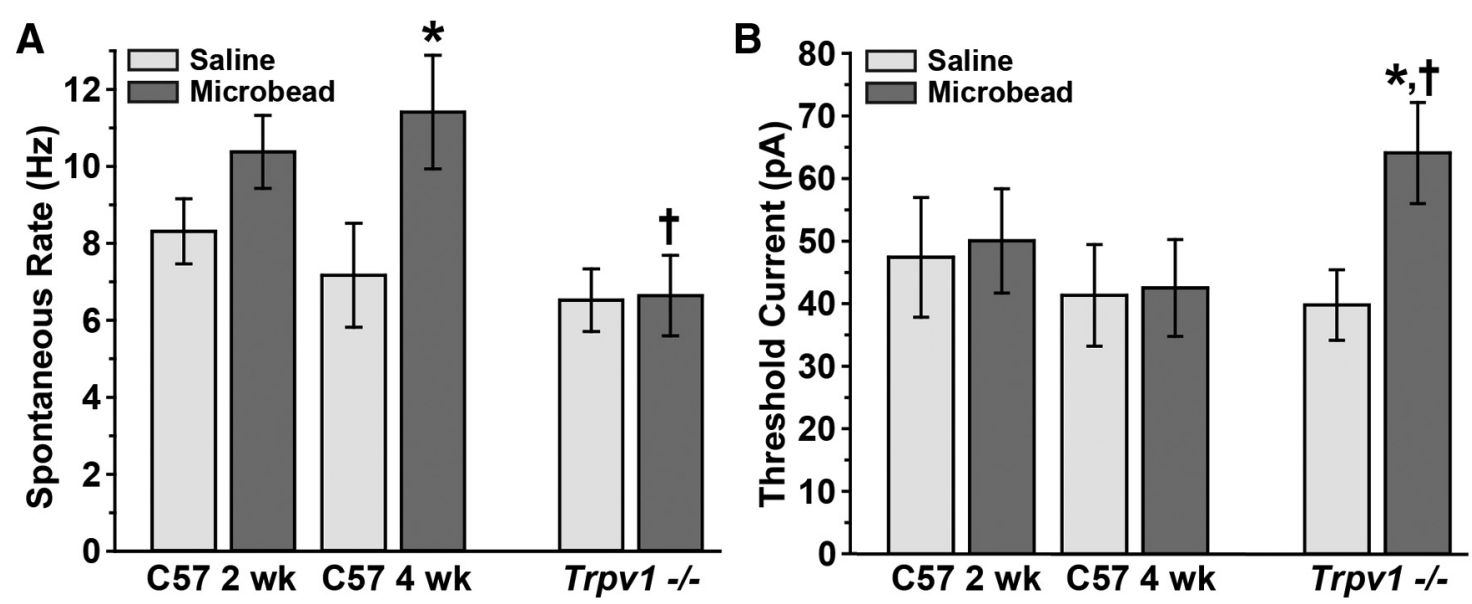

Figure 7. $\quad \operatorname{Trpv} 1^{-1-}$ ganglion cells lack compensatory excitation. $A$, Spontaneous firing rate increases significantly for ganglion cells in $C 574$ week microbead retinas $(11.41 \pm 1.48 \mathrm{~Hz}, n=37$ cells) compared with those in saline retinas $\left(7.17 \pm 1.35 \mathrm{~Hz}, n=31 ;{ }^{*} p=0.025\right)$. The apparent increase for microbead cells in the 2 week group $(10.37 \pm 0.95 \mathrm{~Hz}, n=105 \mathrm{cells})$ compared with saline $(8.31 \pm 0.84 \mathrm{~Hz}, n=68)$ was not significant $(p=0.28)$. Cells in $\operatorname{Trpv} 1^{-1-}$ microbead retina demonstrated significantly less spontaneous activity compared with their $\mathrm{C57}$ counterparts in either cohort $\left(6.64 \pm 1.04 \mathrm{~Hz}, n=34\right.$ cells; $\left.{ }^{\dagger} p \leq 0.048\right)$ and were similar to $\operatorname{Trpv} 1^{-1-}$ saline ganglion cells $(6.52 \pm 0.81, n=33$ cells; $p=0.67)$. Ganglion cell responses in saline retinas did not differ between any group $(p=0.55)$. $\boldsymbol{B}$, Minimum depolarizing current required to induce action potentials in ganglion cells with low spontaneous rates $(<0.5 \mathrm{~Hz})$ was greater for $\operatorname{Trpv} 1^{-/-}$ microbead retinas (64.0. $\pm 8.05, n=25$ cells) compared with $\operatorname{Trpv1} 1^{-\prime-}$ saline $(39.8 \pm 5.6, n=22 ; * 0=0.013)$ and when compared with 4 week $C 57$ microbead ganglion cells $(42.5 \pm 7.7, n=$ $20 ;{ }^{\dagger} p=0.020$ ). Threshold current did not differ between any saline retina cohort $(p=0.55)$.

levels of $\mathrm{Ca}^{2+}$ (Fig. 8C). Coapplication of CAP with EGTA (950 $\mu \mathrm{M})$ to chelate extracellular $\mathrm{Ca}^{2+}$ prevented the $\mathrm{Ca}^{2+}$ increase but not the formation of local nodes (Fig. 8D).

Immunolabeling of the same ganglion cells after Fluo-4 imaging indicated that focal concentrations of TRPV1 corresponded to local nodes of concentrated intracellular $\mathrm{Ca}^{2+}$ induced by CAP treatment (Fig. 8E). When quantified across preparations, compared with vehicle treatment, $1 \mu \mathrm{M}$ CAP increased ganglion cell $\mathrm{Ca}^{2+}$ by threefold, which was quenched entirely by cotreatment with EGTA (Fig. $8 F$ ). Whereas $100 \mathrm{~nm}$ CAP did not increase overall $\mathrm{Ca}^{2+}$ compared with vehicle (Fig. $8 F$ ), it did increase by threefold the density of TRPV1 nodes along stretches of ganglion cell dendrites, as well as node size (Fig. 8G). Thus, activation of TRPV1 by CAP induces translocation of the channel to local dendritic sites that gate focal increases in influx of extracellular $\mathrm{Ca}^{2+}$.

\section{Discussion}

Recently, we found that both $\operatorname{Trpv1} 1^{-/-}$and pharmacological inhibition of the receptor in vivo accelerated degeneration of retinal ganglion cell axons and bodies in response to modest periods (4-5 weeks) of elevated IOP in the microbead occlusion model of induced glaucoma (Ward et al., 2014). Retinal ganglion cells from eyes with elevated IOP had significantly enhanced spontaneous firing rates, a response that was completely absent in $\operatorname{Trpv1^{-/-}}$ ganglion cells. We proposed that TRPV1 intrinsically counters functional degradation of stressed ganglion cells and their axons through a neuroprotective mechanism, as in models of ischemic brain injury (Pegorini et al., 2005; Muzzi et al., 2012). Similar studies have implicated TRPV1 and TRP Canonical 6 as protective mediators of ganglion cell survival in ischemic-reperfusion injury (Nucci et al., 2007).

Because of the high $\mathrm{Ca}^{2+}$ conductance of TRPV1, whether activation is protective or toxic depends greatly on expression levels, the mode of activation, and in some cases interactions with other receptor classes, including cannabinoid receptors (Kim et al., 2007). TRPV1 expression is known to rise with exposure to noxious or stressful stimuli, many of which are activators of the channel (Facer et al., 2007; Schumacher and Eilers, 2010). We found that a single week of microbead-induced elevated IOP increases TRPV1 in ganglion cell bodies and in the inner plexiform layer, in which ganglion cells receive synaptic contacts (Fig. 2). Total retinal Trpv1 mRNA also increased slightly (Fig. 2C). Elevations in TRPV1 were transient, returning to control levels by 5 weeks, and correlated with greater colocalization with excitatory postsynaptic densities (Fig. 3). TRPV1 localization also increases in retinal ganglion cells of the DBA2J mouse model of chronic glaucoma (Sappington et al., 2009), which demonstrates progressive elevations in IOP with age (Libby et al., 2005; Inman et al., 2006). Here, as Trpv1 mRNA rose in the DBA2J retina with elevated IOP and age (Fig. 4A), in situ hybridization against Trpv1 combined with a cell-specific marker (SMI31) showed progressively increased expression in ganglion cells from 6 to 8 months of age (Fig. $4 D-F$ ), when neurodegeneration in the DBA2J is early (Whitmore et al., 2005; Inman et al., 2006; Crish et al., 2010; Howell et al., 2012; for review, see Calkins, 2012). Supporting a protective role, Trpv1 antisense signal was lower in ganglion cells with overt accumulation of phosphorylated neurofilaments (Fig. $4 G, H)$, an indicator of advanced progression in the DBA2J retina (Howell et al., 2007b; Soto et al., 2008).

Our key physiological finding is that, as TRPV1 localization rises transiently in retinal ganglion cells, the capacity of the channels to increase excitability changes as well, as it does in other axonal injury models (Biggs et al., 2007, 2008). In retinas from saline-injected control eyes, pharmacological activation of TRPV1 had a net hyperpolarizing influence on ganglion cell firing rates with most cells demonstrating a decreased rate with drug application (Fig. $6 A-C$ ). However, after 2 weeks of elevated IOP, the net response became depolarizing, with the majority of ganglion cells demonstrating increased excitation with TRPV1 agonism (Fig. 6A,C). This effect was transient. After 4 weeks of elevated IOP, ganglion cells from microbead and saline retinas had the same, mostly hyperpolarizing response to TRPV1 agonists (Fig. 6B,C). The influence of TRPV1 was highly specific, because the synthetic antagonist IRTX nearly completely blunted the effects of the agonists for all ganglion cells (Fig. 6D). Interestingly, although the excitatory effects of TRPV1-specific agonists 

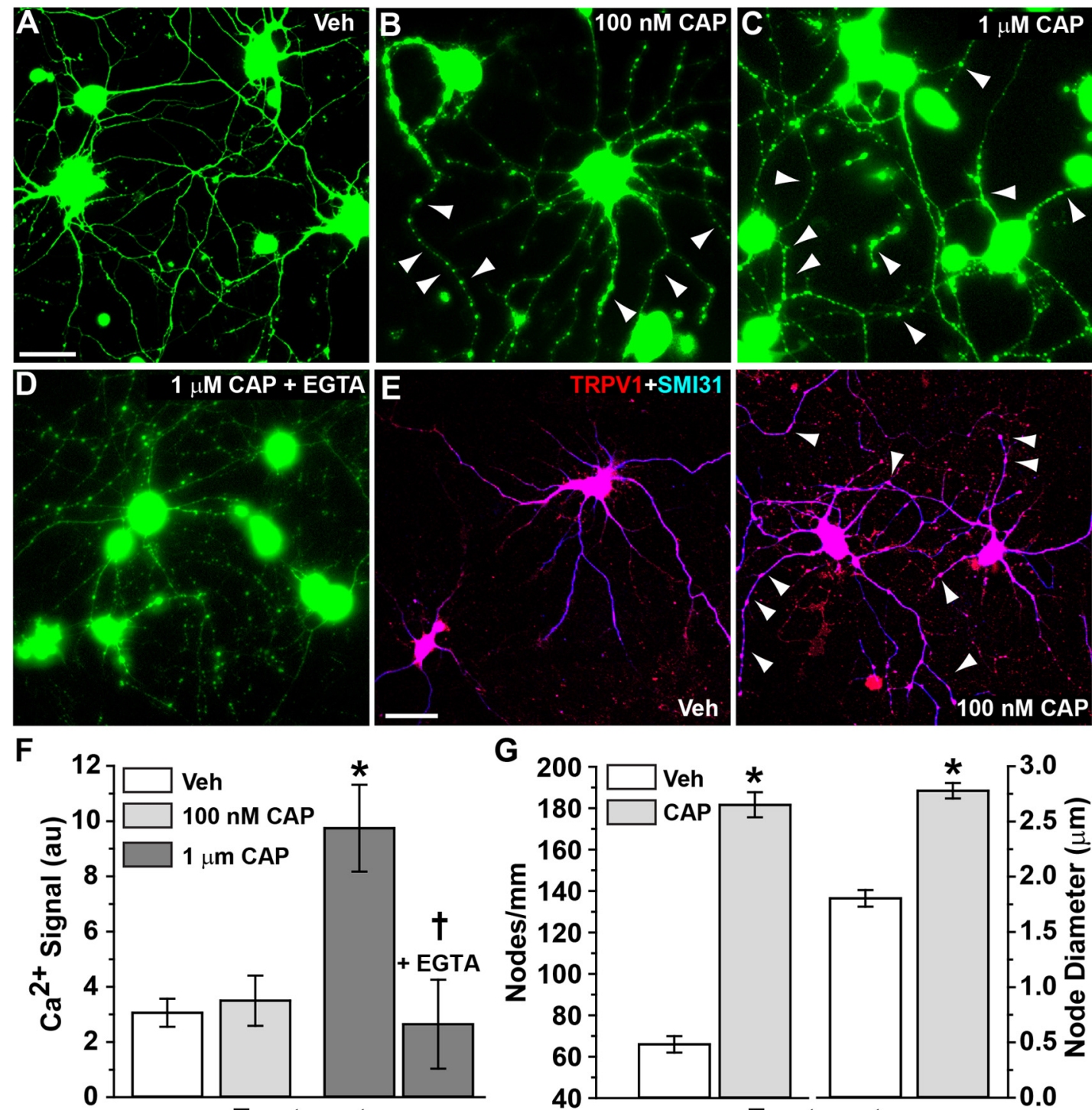

Treatment

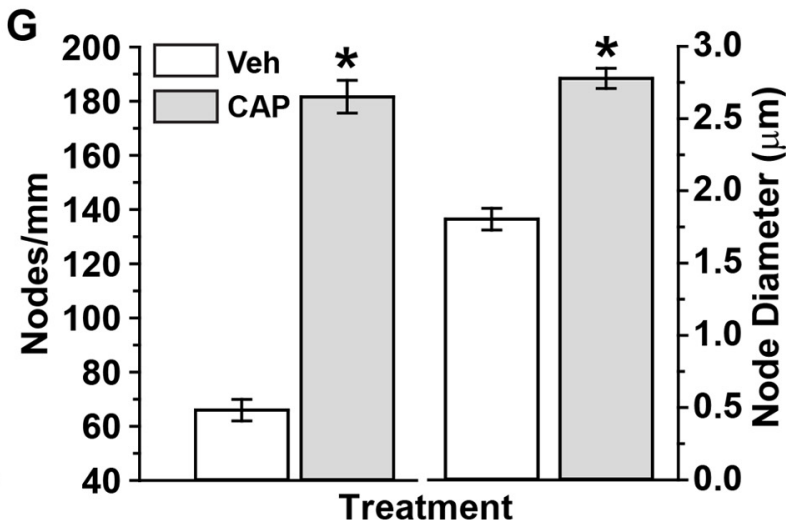

Figure 8. Activation of TRPV1 induces translocation. $\boldsymbol{A}$, Fluo-4-conjugated $\mathrm{Ca}^{2+}$ in isolated retinal ganglion cells distributes evenly in dendritic processes with vehicle (Veh) treatment. $\boldsymbol{B}$, CAP at $100 \mathrm{~nm}$ concentrates $\mathrm{Ca}^{2+}$ in local nodes along dendritic processes (arrowheads). C, Increased CAP (1 $\left.\mu \mathrm{m}\right)$ raises overall $\mathrm{Ca}^{2+}$ including at nodes (arrowheads). D, Cotreatment with EGTA (950 $\left.\mu \mathrm{M}\right)$ to chelate extracellular $\mathrm{Ca}^{2+}$ reduced levels but not CAP-induced nodes. $\boldsymbol{E}$, Immunolabeling for TRPV1 and phosphorylated neurofilaments (SMI31) on the same ganglion cells used for Fluo-4 imaging shows concentrations of TRPV1 corresponding to nodes of increased intracellular $\mathrm{Ca}^{2+}$ with CAP activation (arrowheads). $F$, Quantification of Fluo-4 signal indicates a more than threefold increase with $1 \mu \mathrm{M}$ CAP compared with vehicle ( $\left.{ }^{*} p<0.001\right)$, which was prevented by cotreatment with EGTA ( $\left.{ }^{\dagger} p=0.004\right)$. G, Treatment with $100 \mathrm{~nm}$ CAP increases the density of TRPV1concentrated nodes threefold along stretches of ganglion cell dendrites, as well as their maximum diameter compared with vehicle $\left(^{*} p<0.001\right)$. Scale bars: $\boldsymbol{A}-\boldsymbol{D}, 20 \mu \mathrm{m} ; \boldsymbol{E}, 40 \mu \mathrm{m}$.

were early and transient, commensurate with early changes in expression (Figs. 2, 3), the net influence on spontaneous firing rate was delayed. Although ganglion cells from saline retina had the same spontaneous rate at all times, the rate for ganglion cells from microbead retina gradually increased from 2 to 4 weeks of elevated IOP (Fig. 7A). Ganglion cells from Trpv1 ${ }^{-/}$retina completely lacked this increase, with spontaneous rates that did not differ from saline-retina ganglion cells in the C57 cohorts (Fig. $7 A) . T r p v 1^{-1-}$ ganglion cells from microbead eyes that lacked appreciable spontaneous rates $(<0.5 \mathrm{~Hz})$ also required $\sim 60 \%$ more depolarizing current to fire, again regardless of length of IOP elevation (Fig. 7B). This could indicate that $\operatorname{Trpv1} 1^{-/-}$ganglion cells lack not only the compensatory response but the capacity altogether to sense IOP-related stress. This idea is supported by our results from isolated ganglion cells showing that TRPV1 antagonism blunts pressure-induced increases in intracellular $\mathrm{Ca}^{2+}$ (Sappington et al., 2009).
Colocalization of TRPV1 with PSD-95 on ganglion cell dendrites suggests that the receptor could modulate postsynaptic activity directly (Fig. 3), as does the localization of TRPV1 to dendritic nodes of heightened $\mathrm{Ca}^{2+}$ accumulation in isolated ganglion cells (Figs. 8). Upregulation and activation of TRPV1 are often concurrent with translocation from intracellular binding sites either to different neuronal compartments or the plasma membrane (Zhang et al., 2005; Biggs et al., 2008; Goswami et al., 2010; Schumacher and Eilers, 2010). TRPV1-gated $\mathrm{Ca}^{2+}$ promotes spontaneous excitation and can potentiate responses to glutamate (Marinelli et al., 2003; Xing and Li, 2007; Medvedeva et al., 2008; Jiang et al., 2009; Peters et al., 2010). Evidence for potentiation points to a presynaptic role for TRPV1, through facilitation of glutamate release (Marinelli et al., 2003; Medvedeva et al., 2008). This potentiation supports increased axonal spontaneous firing (Xing and Li, 2007). However, in studies of long-term depression in dentate gyrus, TRPV1 exerts its influence postsyn- 
aptically by suppressing excitatory transmission (Chávez et al., 2010). In this case, EPSCs are reduced by CAP treatment, resembling the reduction in activity we observed for ganglion cells from control retinas (Fig. 6). Typically, synaptic actions of TRPV1-whether presynaptic or postsynaptic - involve complex interactions with glutamatergic signaling machinery and/or cannabinoid pathways (Marinelli et al., 2005; Kim et al., 2007; Chávez et al., 2010). In the retina, multiple cell types besides ganglion cells express TRPV1 at different levels, including both excitatory and inhibitory neurons (for review, see Ryskamp et al., 2014). It is possible that increased TRPV1 expression with elevated IOP reflects also a change in the relative influence of TRPV1-expressing neurons presynaptic to ganglion cells.

Degeneration of retinal ganglion cells in glaucoma is likely initiated by IOP-related stress directed to the highly vulnerable unmyelinated segment of the axon as it passes through the optic nerve head (Burgoyne, 2011; Calkins, 2012). Thus, early pathogenesis is axogenic, involving physiological challenges to the optic projection before outright degeneration (Whitmore et al., 2005; Calkins, 2012; Howell et al., 2012). One of the earliest characteristics is degradation of active transport from the retina to the superior colliculus, the most distal projection for ganglion cell axons (Crish et al., 2010; Lambert et al., 2011; Dapper et al., 2013). Our earlier study showed that both depletion of functional transport to the colliculus and axonal degeneration in the optic nerve proceeded approximately twice as rapidly in $\operatorname{Tr} p v 1^{-1-}$ than in age-matched C57 mice for the same 5 week period of IOP elevation; pharmacological antagonism also accelerated degeneration (Ward et al., 2014).

Together, our results suggest an intriguing possibility. The transient TRPV1-mediated enhancement of ganglion cell excitation induced by elevated IOP appears to support, in unknown ways, a longer-lasting higher spontaneous firing rate that is critical to ganglion cell axon survival, because its absence in $\operatorname{Trp} v 1^{-/-}$retina accelerates degeneration. In the microbead model, even as axon transport is challenged before outright axon loss (Crish et al., 2010; Chen et al., 2011; Dapper et al., 2013), glutamatergic synapses from ganglion cell axons to interneurons in the colliculus persist, defining a window of opportunity for therapeutic intervention (Crish et al., 2010, 2013). Although we have focused on ganglion cells as postsynaptic neurons in the retina, their central purpose is in fact presynaptic, in conveying visual information to brain targets via glutamatergic signaling. Transient activation by CAP or N-OLDA of TRPV1 in axonal boutons of dorsal root ganglion neurons elevates presynaptic $\mathrm{Ca}^{2+}$ to enhance glutamate release to postsynaptic spinal cord neurons (Medvedeva et al., 2008). In a similar way, retinal TRPV1 acting on ganglion cell dendrites could have a distal influence conveyed via enhanced spontaneous activity to conserve glutamatergic signaling at central brain targets. Enhanced TRPV1 excitation in the ganglion cell circuit could serve an early and critical role in boosting spontaneous axonal activity to maintain functional connectivity with brain targets in response to ocular stress.

\section{References}

Aarts MM, Tymianski M (2005) TRPMs and neuronal cell death. Pflug Arch 451:243-249. CrossRef Medline

Agopyan N, Head J, Yu S, Simon SA (2004) TRPV1 receptors mediate particulate matter-induced apoptosis. Am J Physiol Lung Cell Mol Physiol 286:L563-L572. CrossRef Medline

Biggs JE, Yates JM, Loescher AR, Clayton NM, Boissonade FM, Robinson PP (2007) Changes in vanilloid receptor 1 (TRPV1) expression following lingual nerve injury. Eur J Pain 11:192-201. CrossRef Medline
Biggs JE, Yates JM, Loescher AR, Clayton NM, Robinson PP, Boissonade FM (2008) Effect of SB-750364, a specific TRPV1 receptor antagonist, on injury-induced ectopic discharge in the lingual nerve. Neurosci Lett 443 : 41-45. CrossRef Medline

Burgoyne CF (2011) A biomechanical paradigm for axonal insult within the optic nerve head in aging and glaucoma. Exp Eye Res 93:120-132. CrossRef Medline

Calkins DJ (2012) Critical pathogenic events underlying progression of neurodegeneration in glaucoma. Prog Retin Eye Res 31:702-719. CrossRef Medline

Caterina MJ, Leffler A, Malmberg AB, Martin WJ, Trafton J, Petersen-Zeitz KR, Koltzenburg M, Basbaum AI, Julius D (2000) Impaired nociception and pain sensation in mice lacking the capsaicin receptor. Science 288: 306-313. CrossRef Medline

Chávez AE, Chiu CQ, Castillo PE (2010) TRPV1 activation by endogenous anandamide triggers postsynaptic long-term depression in dentate gyrus. Nat Neurosci 13:1511-1518. CrossRef Medline

Chen H, Wei X, Cho KS, Chen G, Sappington R, Calkins DJ, Chen DF (2011) Optic neuropathy due to microbead-induced elevated intraocular pressure in the mouse. Invest Ophthalmol Vis Sci 52:36-44. CrossRef Medline

Cho EY, So KF (1992) Characterization of the sprouting response of axonlike processes from retinal ganglion cells after axotomy in adult hamsters: a model using intravitreal implantation of a peripheral nerve. J Neurocytol 21:589-603. CrossRef Medline

Ciura S, Bourque CW (2006) Transient receptor potential vanilloid 1 is required for intrinsic osmoreception in organum vasculosum lamina terminalis neurons and for normal thirst responses to systemic hyperosmolality. J Neurosci 26:9069-9075. CrossRef Medline

Crish SD, Sappington RM, Inman DM, Horner PJ, Calkins DJ (2010) Distal axonopathy with structural persistence in glaucomatous neurodegeneration. Proc Natl Acad Sci U S A 107:5196-5201. CrossRef Medline

Crish SD, Dapper JD, MacNamee SE, Balaram P, Sidorova TN, Lambert WS, Calkins DJ (2013) Failure of axonal transport induces a spatially coincident increase in astrocyte BDNF prior to synapse loss in a central target. Neuroscience 229:55-70. CrossRef Medline

Daly D, Rong W, Chess-Williams R, Chapple C, Grundy D (2007) Bladder afferent sensitivity in wild-type and TRPV1 knockout mice. J Physiol 583:663-674. CrossRef Medline

Dapper JD, Crish SD, Pang IH, Calkins DJ (2013) Proximal inhibition of p38 MAPK stress signaling prevents distal axonopathy. Neurobiol Dis 59:26-37. CrossRef Medline

Facer P, Casula MA, Smith GD, Benham CD, Chessell IP, Bountra C, Sinisi M, Birch R, Anand P (2007) Differential expression of the capsaicin receptor TRPV1 and related novel receptors TRPV3, TRPV4 and TRPM8 in normal human tissues and changes in traumatic and diabetic neuropathy. BMC Neurol 7:11. CrossRef Medline

Gee KR, Archer EA, Lapham LA, Leonard ME, Zhou ZL, Bingham J, Diwu Z (2000) New ratiometric fluorescent calcium indicators with moderately attenuated binding affinities. Bioorg Med Chem Lett 10:1515-1518. CrossRef Medline

Goswami C, Rademacher N, Smalla KH, Kalscheuer V, Ropers HH, Gundelfinger ED, Hucho T (2010) TRPV1 acts as a synaptic protein and regulates vesicle recycling. J Cell Sci 123:2045-2057. CrossRef Medline

Hanna MC, Calkins DJ (2006) Expression and sequences of genes encoding glutamate receptors and transporters in primate retina determined using $3^{\prime}$-end amplification polymerase chain reaction. Mol Vis 12:961-976. Medline

Ho KW, Ward NJ, Calkins DJ (2012) TRPV1: a stress response protein in the central nervous system. Am J Neurodegener Dis 1:1-14. Medline

Howell GR, Libby RT, Marchant JK, Wilson LA, Cosma IM, Smith RS, Anderson MG, John SW (2007a) Absence of glaucoma in DBA/2J mice homozygous for wild-type versions of Gpnmb and Tyrp1. BMC Genet 8:45. CrossRef Medline

Howell GR, Libby RT, Jakobs TC, Smith RS, Phalan FC, Barter JW, Barbay JM, Marchant JK, Mahesh N, Porciatti V, Whitmore AV, Masland RH, John SW (2007b) Axons of retinal ganglion cells are insulted in the optic nerve early in DBA/2J glaucoma. J Cell Biol 179:1523-1537. CrossRef Medline

Howell GR, Soto I, Zhu X, Ryan M, Macalinao DG, Sousa GL, Caddle LB, MacNicoll KH, Barbay JM, Porciatti V, Anderson MG, Smith RS, Clark AF, Libby RT, John SW (2012) Radiation treatment inhibits monocyte 
entry into the optic nerve head and prevents neuronal damage in a mouse model of glaucoma. J Clin Invest 122:1246-1261. CrossRef Medline

Hwang SJ, Burette A, Rustioni A, Valtschanoff JG (2004) Vanilloid receptor VR1-positive primary afferents are glutamatergic and contact spinal neurons that co-express neurokinin receptor NK1 and glutamate receptors. J Neurocytol 33:321-329. CrossRef Medline

Inman DM, Sappington RM, Horner PJ, Calkins DJ (2006) Quantitative correlation of optic nerve pathology with ocular pressure and corneal thickness in the DBA/2 mouse model of glaucoma. Invest Ophthalmol Vis Sci 47:986-996. CrossRef Medline

Jakobs TC, Koizumi A, Masland RH (2008) The spatial distribution of glutamatergic inputs to dendrites of retinal ganglion cells. J Comp Neurol 510:221-236. CrossRef Medline

Jiang CY, Fujita T, Yue HY, Piao LH, Liu T, Nakatsuka T, Kumamoto E (2009) Effect of resiniferatoxin on glutamatergic spontaneous excitatory synaptic transmission in substantia gelatinosa neurons of the adult rat spinal cord. Neuroscience 164:1833-1844. CrossRef Medline

Jones RC 3rd, Xu L, Gebhart GF (2005) The mechanosensitivity of mouse colon afferent fibers and their sensitization by inflammatory mediators require transient receptor potential vanilloid 1 and acid-sensing ion channel 3. J Neurosci 25:10981-10989. CrossRef Medline

Kanai Y, Nakazato E, Fujiuchi A, Hara T, Imai A (2005) Involvement of an increased spinal TRPV1 sensitization through its up-regulation in mechanical allodynia of CCI rats. Neuropharmacology 49:977-984. CrossRef Medline

Kim SR, Kim SU, Oh U, Jin BK (2006) Transient receptor potential vanilloid subtype 1 mediates microglial cell death in vivo and in vitro via $\mathrm{Ca} 2+-$ mediated mitochondrial damage and cytochrome $\mathrm{c}$ release. J Immunol 177:4322-4329. CrossRef Medline

Kim SR, Chung YC, Chung ES, Park KW, Won SY, Bok E, Park ES, Jin BK (2007) Roles of transient receptor potential vanilloid subtype 1 and cannabinoid type 1 receptors in the brain: neuroprotection versus neurotoxicity. Mol Neurobiol 35:245-254. CrossRef Medline

Koulen P, Fletcher EL, Craven SE, Bredt DS, Wässle H (1998) Immunocytochemical localization of the postsynaptic density protein PSD-95 in the mammalian retina. J Neurosci 18:10136-10149. Medline

Kreitzer AC, Gee KR, Archer EA, Regehr WG (2000) Monitoring presynaptic calcium dynamics in projection fibers by in vivo loading of a novel calcium indicator. Neuron 27:25-32. CrossRef Medline

Lambert WS, Ruiz L, Crish SD, Wheeler LA, Calkins DJ (2011) Brimonidine prevents axonal and somatic degeneration of retinal ganglion cell neurons. Mol Neurodegener 6:4. CrossRef Medline

Leonelli M, Martins DO, Kihara AH, Britto LR (2009) Ontogenetic expression of the vanilloid receptors TRPV1 and TRPV2 in the rat retina. Int J Dev Neurosci 27:709-718. CrossRef Medline

Leonelli M, Martins DO, Britto LR (2010) TRPV1 receptors are involved in protein nitration and Muller cell reaction in the acutely axotomized rat retina. Exp Eye Res 91:755-768. CrossRef Medline

Leonelli M, Martins DO, Britto LR (2013) Retinal cell death induced by TRPV1 activation involves NMDA signaling and upregulation of nitric oxide synthases. Cell Mol Neurobiol 33:379-392. CrossRef Medline

Li DP, Chen SR, Pan HL (2004) VR1 receptor activation induces glutamate release and postsynaptic firing in the paraventricular nucleus. J Neurophysiol 92:1807-1816. CrossRef Medline

Li HB, Mao RR, Zhang JC, Yang Y, Cao J, Xu L (2008) Antistress effect of TRPV1 channel on synaptic plasticity and spatial memory. Biol Psychiatry 64:286-292. CrossRef Medline

Libby RT, Anderson MG, Pang IH, Robinson ZH, Savinova OV, Cosma IM, Snow A, Wilson LA, Smith RS, Clark AF, John SW (2005) Inherited glaucoma in DBA/2J mice: pertinent disease features for studying the neurodegeneration. Vis Neurosci 22:637-648. Medline

Liedtke W (2006) Transient receptor potential vanilloid channels functioning in transduction of osmotic stimuli. J Endocrinol 191:515-523. CrossRef Medline

Lin SY, Corey DP (2005) TRP channels in mechanosensation. Curr Opin Neurobiol 15:350-357. CrossRef Medline

Livak KJ, Schmittgen TD (2001) Analysis of relative gene expression data using real-time quantitative PCR and the 2(-Delta Delta C(T)) method. Methods 25:402-408. CrossRef Medline

Ma W, Zhang Y, Bantel C, Eisenach JC (2005) Medium and large injured dorsal root ganglion cells increase TRPV-1, accompanied by increased
alpha2C-adrenoceptor co-expression and functional inhibition by clonidine. Pain 113:386-394. CrossRef Medline

Maione S, Cristino L, Migliozzi AL, Georgiou AL, Starowicz K, Salt TE, Di Marzo V (2009) TRPV1 channels control synaptic plasticity in the developing superior colliculus. J Physiol 587:2521-2535. CrossRef Medline

Marinelli S, Di Marzo V, Berretta N, Matias I, Maccarrone M, Bernardi G, Mercuri NB (2003) Presynaptic facilitation of glutamatergic synapses to dopaminergic neurons of the rat substantia nigra by endogenous stimulation of vanilloid receptors. J Neurosci 23:3136-3144. Medline

Marinelli S, Pascucci T, Bernardi G, Puglisi-Allegra S, Mercuri NB (2005) Activation of TRPV1 in the VTA excites dopaminergic neurons and increases chemical- and noxious-induced dopamine release in the nucleus accumbens. Neuropsychopharmacology 30:864-870. CrossRef Medline

Medvedeva YV, Kim MS, Usachev YM (2008) Mechanisms of prolonged presynaptic $\mathrm{Ca} 2+$ signaling and glutamate release induced by TRPV1 activation in rat sensory neurons. J Neurosci 28:5295-5311. CrossRef Medline

Miller BA (2006) The role of TRP channels in oxidative stress-induced cell death. J Membr Biol 209:31-41. CrossRef Medline

Mutai H, Heller S (2003) Vertebrate and invertebrate TRPV-like mechanoreceptors. Cell Calcium 33:471-478. CrossRef Medline

Muzzi M, Felici R, Cavone L, Gerace E, Minassi A, Appendino G, Moroni F, Chiarugi A (2012) Ischemic neuroprotection by TRPV1 receptorinduced hypothermia. J Cereb Blood Flow Metab 32:978-982. CrossRef Medline

Nucci C, Gasperi V, Tartaglione R, Cerulli A, Terrinoni A, Bari M, De Simone C, Agrò AF, Morrone LA, Corasaniti MT, Bagetta G, Maccarrone M (2007) Involvement of the endocannabinoid system in retinal damage after high intraocular pressure-induced ischemia in rats. Invest Ophthalmol Vis Sci 48:2997-3004. CrossRef Medline

Pegorini S, Braida D, Verzoni C, Guerini-Rocco C, Consalez GG, Croci L, Sala M (2005) Capsaicin exhibits neuroprotective effects in a model of transient global cerebral ischemia in Mongolian gerbils. Br J Pharmacol 144: 727-735. CrossRef Medline

Peters JH, McDougall SJ, Fawley JA, Smith SM, Andresen MC (2010) Primary afferent activation of thermosensitive TRPV1 triggers asynchronous glutamate release at central neurons. Neuron 65:657-669. CrossRef Medline

Pingle SC, Matta JA, Ahern GP (2007) Capsaicin receptor: TRPV1 a promiscuous TRP channel. Handb Exp Pharmacol 155-171. CrossRef

Plant TD, Zollner C, Mousa SA, Oksche A (2006) Endothelin-1 potentiates capsaicin-induced TRPV1 currents via the endothelin A receptor. Exp Biol Med (Maywood) 231:1161-1164. Medline

Quigley HA, Broman AT (2006) The number of people with glaucoma worldwide in 2010 and 2020. Br J Ophthalmol 90:262-267. CrossRef Medline

Reilly CA, Johansen ME, Lanza DL, Lee J, Lim JO, Yost GS (2005) Calciumdependent and independent mechanisms of capsaicin receptor (TRPV1)mediated cytokine production and cell death in human bronchial epithelial cells. J Biochem Mol Toxicol 19:266-275. CrossRef Medline

Rong W, Hillsley K, Davis JB, Hicks G, Winchester WJ, Grundy D (2004) Jejunal afferent nerve sensitivity in wild-type and TRPV1 knockout mice. J Physiol 560:867-881. CrossRef Medline

Ryskamp DA, Witkovsky P, Barabas P, Huang W, Koehler C, Akimov NP, Lee SH, Chauhan S, Xing W, Rentería RC, Liedtke W, Krizaj D (2011) The polymodal ion channel transient receptor potential vanilloid 4 modulates calcium flux, spiking rate, and apoptosis of mouse retinal ganglion cells. J Neurosci 31:7089-7101. CrossRef Medline

Ryskamp DA, Redmon S, Jo AO, Križaj D (2014) TRPV1 and endocannabinoids: emerging molecular signals. Cells 3:914-938. CrossRef Medline

Sappington RM, Chan M, Calkins DJ (2006) Interleukin-6 protects retinal ganglion cells from pressure-induced death. Invest Ophthalmol Vis Sci 47:2932-2942. CrossRef Medline

Sappington RM, Sidorova T, Long DJ, Calkins DJ (2009) TRPV1: contribution to retinal ganglion cell apoptosis and increased intracellular $\mathrm{Ca} 2+$ with exposure to hydrostatic pressure. Invest Ophthalmol Vis Sci 50:717728. CrossRef Medline

Sappington RM, Carlson BJ, Crish SD, Calkins DJ (2010) The microbead occlusion model: a paradigm for induced ocular hypertension in rats and mice. Invest Ophthalmol Vis Sci 51:207-216. CrossRef Medline

Schumacher MA, Eilers H (2010) TRPV1 splice variants: structure and function. Front Biosci (Landmark Ed) 15:872-882. CrossRef Medline 
Scotland RS, Chauhan S, Davis C, De Felipe C, Hunt S, Kabir J, Kotsonis P, Oh U, Ahluwalia A (2004) Vanilloid receptor TRPV1, sensory C-fibers, and vascular autoregulation: a novel mechanism involved in myogenic constriction. Circ Res 95:1027-1034. CrossRef Medline

Soto I, Oglesby E, Buckingham BP, Son JL, Roberson ED, Steele MR, Inman DM, Vetter ML, Horner PJ, Marsh-Armstrong N (2008) Retinal ganglion cells downregulate gene expression and lose their axons within the optic nerve head in a mouse glaucoma model. J Neurosci 28:548-561. CrossRef Medline

Spicarova D, Palecek J (2009) The role of the TRPV1 endogenous agonist $\mathrm{N}$-Oleoyldopamine in modulation of nociceptive signaling at the spinal cord level. J Neurophysiol 102:234-243. CrossRef Medline

Treesukosol Y, Lyall V, Heck GL, DeSimone JA, Spector AC (2007) A psychophysical and electrophysiological analysis of salt taste in Trpv1 null mice. Am J Physiol Regul Integr Comp Physiol 292:R1799-R1809. CrossRef Medline

Vennekens R, Menigoz A, Nilius B (2012) TRPs in the brain. Rev Physiol Biochem Pharmacol 163:27-64. CrossRef Medline

Wahl P, Foged C, Tullin S, Thomsen C (2001) Iodo-resiniferatoxin, a new potent vanilloid receptor antagonist. Mol Pharmacol 59:9-15. CrossRef Medline

Wang X, Teng L, Li A, Ge J, Laties AM, Zhang X (2010) TRPC6 channel protects retinal ganglion cells in a rat model of retinal ischemia/ reperfusion-induced cell death. Invest Ophthalmol Vis Sci 51:5751-5758. CrossRef Medline

Ward NJ, Ho KW, Lambert WS, Weitlauf C, Calkins DJ (2014) Absence of transient receptor potential vanilloid-1 accelerates stress-induced axonopathy in the optic projection. J Neurosci 34:3161-3170. CrossRef Medline

Whitmore AV, Libby RT, John SW (2005) Glaucoma: thinking in new ways-a role for autonomous axonal self-destruction and other compartmentalised processes? Prog Retin Eye Res 24:639-662. CrossRef Medline

Xing J, Li J (2007) TRPV1 receptor mediates glutamatergic synaptic input to dorsolateral periaqueductal gray (dl-PAG) neurons. J Neurophysiol 97: 503-511. CrossRef Medline

Zhang X, Huang J, McNaughton PA (2005) NGF rapidly increases membrane expression of TRPV1 heat-gated ion channels. EMBO J 24:42114223. CrossRef Medline 